\title{
Quality of life of people living with HIV/AIDS treated by the specialized service in Vitória-ES, Brazil
}

Gabriella Barreto Soares ${ }^{1}$

Cléa Adas Saliba Garbin ${ }^{1}$

Tânia Adas Saliba Rovida ${ }^{1}$

Artênio José Ísper Garbin ${ }^{1}$

${ }^{1}$ Departamento de Odontologia Infanti e Social, Faculdade de Odontologia de Araçatuba, Universidade Estadual

Paulista Júlio de Mesquita Filho. R. José Bonifácio 1193, Vila Mendonça. 16015-050 Araçatuba SP Brasil.gabriella.barreto@ yahoo.com.br

\begin{abstract}
The aim of this study is to establish the factors that influence the quality of life of people living with HIV/AIDS being treated at a specialized public service. The participants answered the questionnaire on sociodemographic conditions, issues related to HIV and daily habits. The quality of life was analyzed using the HIV/AIDS-targeted quality of life (HAT-QoL) instrument with 42 items divided into 9 fields: General Activity, Sexual Activity, Confidentiality Concerns, Health Concerns, Financial Concerns, HIV Awareness, Satisfaction with Life, Issues related to Medication and Trust in the Physician. Bivariate and multiple linear regressions were performed. Of the participants, 53.1\% were women and had a mean age of 42 years. In analyzing the quality of life, the HAT-QoL domain with the lowest average was Financial Concerns (39.4), followed by Confidentiality Concerns (43.2), Sexual Activity (55.2) and Health Concerns (62. 88). There was an association between the variables: not being gainfully employed $(p<0.001)$, being mulatto or black $(p=0.045)$ and alcohol consumption ( $p=$ 0.041 ) with the worst quality of life scores. Inadequate socioeconomic and health conditions had a negative impact on the quality of life of people with HIV/AIDS.
\end{abstract}

Key words HIV, Quality of life, Health services 


\section{Introduction}

More than 30 years since the discovery of the first case of HIV / AIDS in the world, the Acquired Immunodeficiency Syndrome (AIDS) is still considered a major problem for public health. Despite scientific advances and investments for control and therapy, there is a continuous growth of the infection in the population. Only in Brazil are recorded, on average, 35,000 new cases of AIDS per year ${ }^{1,2}$.

Worldwide, it is estimated that in 2012 there were 35.3 million people between men, women and children infected with HIV. Only in 2012, 2.3 million people were infected with HIV and 1.6 million died from AIDS, mostly due to inadequate access to treatment and attention services ${ }^{3}$. In Brazil, since the identification of the first case of AIDS, from 1980 until June 2012, 656,701 cases were identified, with more than 253,706 deaths, which have the underlying cause defined as "diseases by the HIV virus." The disease is concentrated in sub-populations aged 20 to 59 years, with 11 years of study and a gender ratio of 1.7 men for every woman with AIDS².

Advances in antiretroviral therapy (ART) led to a reduction in morbidity and mortality from AIDS, and population studies show improvement in survival of patients with this disease, having at 25, a median life expectancy of 32.5 years from the moment they start the treatment ${ }^{4}$.

In 1996, in a pioneering and innovative way, Brazil signed the law guaranteeing universal free access to medicines for people with HIV / AIDS ${ }^{5,6}$. This technological development has changed the profile of the epidemic in the sense of its chronicity, providing opportunities to individuals with HIV / AIDS to live better with the disease. That is, the antiretroviral therapy (ART) enabled the transformation of a syndrome that previously was culturally perceived as a result of a death foretold, in a disease with prospects of chronicity?

This therapy has provided considerable benefits to its user, such as increased survival, decrease in hospitalizations and the occurrence of opportunistic complications and mortality associated with HIV / AIDS 8 . The Ministry of Health points out that ten years after the implementation of this policy in Brazil, 180,000 people were already receiving treatment in the country and there was a $34 \%$ reduction in mortality and morbidity in $70 \%$ of AIDS cases, considering only the period between 1996 and 2002.

With the improvement in life expectancy of these people, the quality of life becomes an im- portant tool for evaluating the health of these individuals. The variation in the Brazilian population's quality of life has created various social strata in which they operate vulnerable subgroups to HIV / AIDS, increasingly associated with the impoverishment process. This fact has contributed to situations of abandonment of treatment, worsening of the disease and, consequently, increased spending on treatment of complications of people living with HIV / AIDS $^{10}$.

Little research has been conducted that evaluated the quality of life of people living with HIV / AIDS in Brazil. Thus, the present study investigated the quality of life associated with sociodemographic conditions, issues related to HIV, health habits of people living with HIV / AIDS assisted in the publicreference service in Vitoria (ES), Brazil.

\section{Methodology}

This is an exploratory quantitative study of cross-sectional analytical cut, held in the public health service provided to people living with HIV/AIDS, STD / AIDS Reference Center, which operates since 1992 in Vitoria (ES), Brazil.

Around 1,500 people living with HIV / AIDS are accompanied by the STD / AIDS Reference Centre, and on this basis, the sample size (n) was calculated by a Simple Random Sample, with a total of 177 patients, margin of error of $7 \%$ and a 95\% confidence level. The sample selection was random, since they were attended to by the service. Included were patients with a confirmed diagnosis of HIV infection, above 18 years of age and who agreed to participate in the study.

Data collection was held for four months in 2012, after a pilot study in which all variables were tested.

The quality of life data were collected by a validated HAT-QoLinstrument, prepared by Holmes and Shea ${ }^{11}$, originally written in English, but translated and validated in Brazil by Galvão et al. ${ }^{12}$. This instrument was selected to be specific for assessing the quality of life of people living with HIV / AIDS, and has good psychometric properties, good internal consistency and evidence of construct validity. The HAT-QoL has 42 items divided into nine domains: General Activity, Sexual Activity, Secrecy concerns, Health Concerns, Financial Concerns, Awareness about HIV, Satisfaction with Life, Issues related to medication and Confidence in the doctor. The response for all items is obtained through a Likert 
scale that contains: all the time, most of the time, some of the time, a short time and no part of the time. For each question, only an option is written down that corresponds to that which best characterizes the last four weeks experienced by the patient. The scores are calculated according to the answers and range from one to five, with one representing a worst state and five in a better state or condition. The scores obtained in each domain are transformed into an index-weighted from $0-100$, and the closer the index is to 100 , the better the quality of life $\mathrm{e}^{12}$.

The data relating to sociodemographic questions, issues related to HIV and habits were obtained through a structured questionnaire, developed specifically for this study. The sociodemographic variables include: nationality, age, gender, race, marital status, education, employment status and family income. Related to HIV and habits are: viral load, CD4 count, date of diagnosis of HIV infection mode, use of antiretroviral therapy, smoking habits, alcohol consumption, drug use and condom use before and after the diagnosis of the disease.

Descriptive analyzes were performed for the sociodemographic characterization of the population, through measures of central tendency (single frequency, mean and median) and measures of dispersion (standard deviation). The sample involved in the research set normal probability distributions, verified by the Kolmogorov and Smirnov tests $(\mathrm{p}=0.100)$, and the hypotheses were verified with the help of parametric statistics. The region for the rejection or not any of these hypotheses considered a significance level of 0.05. Statistical analysis of variance (ANOVA) and multiple linear regression tests with elimination of non-significant variables were performed. The selection of independent variables for the multiple linear regression models was performed according to a stepwise model. After adjusting the multiple linear regression models, with a $95 \%$ confidence interval, the $\mathrm{p}$ - values were estimated. All statistical analyzes were performed using the SPSS version 17.0 software.

The study was approved by the Ethics in Research Committee with human beings of the Paulista State University, Araçatuba Dental School and performed with the understanding and written consent from each participant.

\section{Results}

Of the 177 study participants, more than half of the sample were women $(53.1 \%)$, with a mean age of 42 years. Most were mixed $(61.6 \%)$ and was not in a steady relationship (48.6\%). As for education, $53.1 \%$ had eight years or less of schooling and $7.3 \%$ could not read and write. Of the respondents, $20.3 \%$ were not employed and $63.8 \%$ had a monthly income of one to two minimum wages (Table 1 ).

Regarding the tests, $78.2 \%$ had CD4 counts greater than 350 cells $/ \mathrm{mm}^{3}$, and $61.6 \%$ of undetectable viral load. As for the time of discovery of HIV diagnosis, $35.0 \%$ said they had more than 10 years, and $86.4 \%$ of patients were between 20 to 50 years when they received the result. The contamination was via heterosexual relationship in $55.9 \%$ of the respondents and $53.1 \%$ said they did not know how they contracted the virus. Most patients were ART users (77.4\%). Of the

Table 1. Sociodemographic characteristics of people living with HIV / AIDS assisted at the HIV / AIDS Reference Center, Vitoria, Brazil. 2012.

\begin{tabular}{|c|c|c|}
\hline Variables & Frequency & $\%$ \\
\hline \multicolumn{3}{|l|}{ Gender } \\
\hline Feminine & 94 & 53.1 \\
\hline Masculine & 83 & 46.9 \\
\hline \multicolumn{3}{|l|}{ Race } \\
\hline White & 30 & 16.9 \\
\hline Black & 38 & 21.5 \\
\hline Brown & 109 & 61.6 \\
\hline \multicolumn{3}{|l|}{ Marital status } \\
\hline Single & 86 & 48.6 \\
\hline Married & 27 & 15.3 \\
\hline Widowed & 13 & 7.3 \\
\hline Common Law & 31 & 17.5 \\
\hline Separated/Divorced & 20 & 11.3 \\
\hline \multicolumn{3}{|l|}{ Education } \\
\hline Illiterate & 13 & 7.3 \\
\hline 8 or $<$ years of study & 94 & 53.1 \\
\hline 9 to 11 years of study & 51 & 28.8 \\
\hline 12 or $>$ years of study & 19 & 10.7 \\
\hline \multicolumn{3}{|l|}{ Work link } \\
\hline Employed & 141 & 79.7 \\
\hline Unemployed & 36 & 20.3 \\
\hline \multicolumn{3}{|l|}{ Family income } \\
\hline Less than $1 \mathrm{MS}$ & 18 & 10.2 \\
\hline 1 to $2 \mathrm{MS}$ & 113 & 63.8 \\
\hline 3 to $4 \mathrm{MS}$ & 33 & 18.6 \\
\hline More than 4 MS & 10 & 5.7 \\
\hline None & 3 & 1.7 \\
\hline
\end{tabular}


patients, $77.4 \%$ did not smoke, $67.2 \%$ did not consume alcohol and $95.5 \%$ of patients said they did not make use of illicit drugs. Regarding the use of condoms during sexual intercourse, $67.8 \%$ said they always use and $6.8 \%$ said they never use, even after the discovery of contamination.

In assessing the QoL, the domain with the lowest average was Financial concern (39.4), followed by Concern with secrecy (43.2), Sexual activities (55.2) and Health concerns (62.88). And the highest averages were: Confidence in the doctor (96.18) and Issues related to medication (86.54) (Table 2).

The results of the bivariate analysis between the mean values of the HAT-QoL domains with the sociodemographic variables, issues related to HIV, and health habits, can be seen in Tables 3 and 4 .

In the multiple linear regression model for the Financial concern domain, it was associated with higher variable scores: higher level of education and do not smoke, while not having a work link was associated with lower scores (Table 5).

In the Secrecy concern domain, older age was positively associated with better scores, while the fact that being brown or black had a negative association. There was a negative association to the Sexual activity domain, not having awork link and alcohol consumption.

In the analysis of the Heath concern domain, being male, have less age and not using illicit drugs were associated with higher scores on the QoL.

\section{Discussion}

Most patients attending the STD / AIDS Reference Center in Victoria were of poor income and had little schooling, as seen in the literature that HIV infection has greater weight on the disadvantaged and the socially marginalized ${ }^{13}$.

Another important aspect is in relation to contamination for heterosexual relationships, which is in agreement with the epidemiological profile of HIV for a few years now: heterosexuals and women, internalization and pauperization ${ }^{14-16}$.

In the analysis of the scores of the quality of life domains, the results showed that the lowest averages are: Financial concerns, Secrecy concerns, Sexual activity and Health concerns, results that corroborate the findings of other studies using the HAT-QoL scale ${ }^{11,12,17}$.

The obtained average rate (39.4), in the Financial concern domain probably was due to the low per capita income of the respondents, which hinders the survival of the individual. This finding may indicate that income, in addition todeterring its value linked to living conditions and services, may influence the health status, which further hinders their integration into the work force ${ }^{18}$. People living with HIV / AIDS who have no work links have a worse quality of life than those that work, and this is also observed in another study ${ }^{10}$. Therefore, the chronic disease brings new changes, including issues related to occupation, and employment does not only have the importance of financial benefit, but is also a form of social and emotional integration, and identity $^{19,20}$.

The participants in this study, with regards to concern with secrecy, were even affected in the demand for health care because these patients stopped going to the doctor or other health professionals for fear of having to report that they have the HIV virus and suffer prejudice on account of the unpreparedness of the profession$\mathrm{a}^{21}$. Therefore, concern about confidentiality is a

Table 2. HIV / AIDS assisted in the HIV / AIDS Reference Center, Vitoria, Brazil. 2012.

\begin{tabular}{lccc}
\hline \multicolumn{1}{c}{ Domains } & Average & SD & Alpha Cronbach's \\
\hline Financial concern & 39.40 & 33.94 & 0.67 \\
Concerns about the confidentiality of infection & 43.25 & 27.38 & 0.71 \\
Sexual Activity & 55.24 & 38.70 & 0.71 \\
Health concerns & 62.88 & 19.41 & 0.65 \\
Awareness about HIV & 74.99 & 32.40 & 0.62 \\
General activity & 75.86 & 24.46 & 0.64 \\
Satisfaction with life & 78.54 & 27.99 & 0.61 \\
Issues related to medication & 86.84 & 18.06 & 0.69 \\
Confidence in the doctor & 96.18 & 13.56 & 0.70 \\
\hline
\end{tabular}


Table 3. Bivariate analysis of standardized scores of the HAT-QoL domains according to sociodemographic variables of people living with HIV / AIDS assisted in the HIV / AIDS Reference Center, Vitoria, Brazil. 2012.

\begin{tabular}{|c|c|c|c|c|c|}
\hline Variables & $\begin{array}{l}\text { General } \\
\text { Activity }\end{array}$ & $\begin{array}{c}\text { Sexual } \\
\text { Activity }\end{array}$ & $\begin{array}{l}\text { Secrecy } \\
\text { Concern }\end{array}$ & $\begin{array}{l}\text { Health } \\
\text { Concern }\end{array}$ & $\begin{array}{l}\text { Financial } \\
\text { Concern }\end{array}$ \\
\hline \multicolumn{6}{|l|}{ Age } \\
\hline $18-34$ & 81.8 & 65.4 & 35.1 & 55.6 & 48.4 \\
\hline $35-44$ & 76.4 & 59.5 & 41.2 & 61.8 & 30.7 \\
\hline $45-70$ & 71.8 & 45.2 & 49.8 & 68.0 & 42.2 \\
\hline$P$ value & 0.109 & 0.014 & 0.017 & 0.004 & 0.021 \\
\hline \multicolumn{6}{|l|}{ Gender } \\
\hline Feminine & 72.0 & 45.8 & 39.0 & 58.8 & 33.1 \\
\hline Masculine & 80.2 & 65.8 & 47.7 & 67.4 & 46.4 \\
\hline$P$ value & 0.025 & 0.001 & 0.041 & 0.003 & 0.009 \\
\hline \multicolumn{6}{|l|}{ Race } \\
\hline White & 72.3 & 59.9 & 55.5 & 64.8 & 44.4 \\
\hline Black & 76.3 & 52.8 & 40.2 & 63.5 & 42.1 \\
\hline Brown & 76.6 & 54.7 & 40.9 & 62.1 & 37.0 \\
\hline $\mathrm{P}$ value & 0.692 & 0.740 & 0.026 & 0.773 & 0.491 \\
\hline \multicolumn{6}{|l|}{ Marital Status } \\
\hline Single/ Common Law & 80.2 & 54.8 & 45.2 & 62.9 & 38.8 \\
\hline Married & 74.0 & 70.0 & 46.2 & 66.4 & 38.3 \\
\hline Widowed & 63.0 & 12.8 & 36.5 & 61.1 & 43.7 \\
\hline Separated/Divorced & 74.1 & 50.4 & 48.7 & 64.5 & 45.1 \\
\hline $\mathrm{P}$ value & 0.114 & 0.000 & 0.216 & 0.687 & 0.900 \\
\hline \multicolumn{6}{|l|}{ Education } \\
\hline Illiterate & 62.6 & 50.6 & 42.6 & 66.1 & 18.3 \\
\hline 8 or $<$ years of study & 76.8 & 50.5 & 44.3 & 61.7 & 37.3 \\
\hline 9 years or more of study & 75.1 & 57.7 & 42.6 & 62.7 & 42.4 \\
\hline$P$ value & 0.162 & 0.079 & 0.921 & 0.683 & 0.015 \\
\hline \multicolumn{6}{|l|}{ Work link } \\
\hline Employed & 84.4 & 69.7 & 36.7 & 64.4 & 46.7 \\
\hline Unemployed & 67.9 & 41.8 & 49.2 & 61.4 & 32.5 \\
\hline $\mathrm{P}$ value & 0.000 & 0.000 & 0.002 & 0.296 & 0.005 \\
\hline \multicolumn{6}{|l|}{ Family income } \\
\hline Less than $1 \mathrm{MS}$ & 57.0 & 41.6 & 52.5 & 56.1 & 18.0 \\
\hline 1 to $2 \mathrm{MS}$ & 77.0 & 53.1 & 41.0 & 63.8 & 39.2 \\
\hline 3 to $4 \mathrm{MS}$ & 83.7 & 68.6 & 47.2 & 66.2 & 53.5 \\
\hline More than 4 MS & 84.4 & 55.0 & 36.0 & 61.0 & 49.0 \\
\hline $\mathrm{P}$ value & 0.002 & 0.146 & 0.684 & 0.557 & 0.006 \\
\hline
\end{tabular}

very common situation among these individuals, which happens because of the fear of being seen as a carrier of a disease still very stigmatized by society. This makes having a double life, because only a few people from their friendships are chosen to know of their serological condition ${ }^{15}$.

Life with HIV / AIDS leads to changes in the sexual activity of people, and the conditions under which they find themselves due to infection lead to fear of sexual intercourse, which makes for avoiding relationships, even having sexual desires $^{22}$.
This implies commitment in the sexual activity domain on the quality of life, and the fact that having no work links and alcohol consumption further strengthened to a worse quality of life.

The fear of being abandoned and rejected by the partner is an aspect due to the seropositivity of HIV, and is present in the lives of individuals with HIV / AIDS ${ }^{23}$. The possibility of maintaining emotional-sexual relationships is a key aspect in the lives of individuals with HIV / AIDS that contributes to a better QoL. The partner is an important source of emotional support, which can 


\begin{tabular}{|c|c|c|c|c|c|}
\hline \multicolumn{6}{|l|}{1080} \\
\hline \multirow{2}{*}{\multicolumn{6}{|c|}{ Table 3. continuation }} \\
\hline & & & & & \\
\hline & Variables & $\begin{array}{c}\text { HIV } \\
\text { Awareness }\end{array}$ & $\begin{array}{l}\text { Satisfaction } \\
\text { with Life }\end{array}$ & $\begin{array}{c}\text { Issues related to } \\
\text { medication }\end{array}$ & $\begin{array}{c}\text { Confidence } \\
\text { in doctor }\end{array}$ \\
\hline & \multicolumn{5}{|l|}{ Age } \\
\hline & $18-34$ & 67.7 & 81.8 & 84.2 & 92.6 \\
\hline & $35-44$ & 70.8 & 77.2 & 88.6 & 97.7 \\
\hline & $45-70$ & 83.2 & 77.7 & 86.6 & 96.7 \\
\hline & P value & 0.021 & 0.687 & 0.476 & 0.157 \\
\hline & \multicolumn{5}{|l|}{ Gender } \\
\hline & Feminine & 69.0 & 72.0 & 85.1 & 94.9 \\
\hline & Masculine & 81.7 & 85.8 & 88.7 & 97.5 \\
\hline & $\mathrm{P}$ value & 0.009 & 0.001 & 0.184 & 0.198 \\
\hline & \multicolumn{5}{|l|}{ Race } \\
\hline & White & 82.5 & 75.6 & 92.3 & 98.9 \\
\hline & Black & 76.9 & 81.8 & 87.2 & 99.1 \\
\hline & Brown & 72.2 & 78.1 & 85.1 & 94.4 \\
\hline & P value & 0.285 & 0.644 & 0.158 & 0.089 \\
\hline & \multicolumn{5}{|l|}{ Marital Status } \\
\hline & Single/ Common Law & 73.8 & 80.0 & 88.0 & 97.9 \\
\hline & Married & 85.5 & 82.2 & 82.8 & 97.2 \\
\hline & Widowed & 64.7 & 64.9 & 89.8 & 91.6 \\
\hline & Separated/Divorced & 77.9 & 76.8 & 85.9 & 90.8 \\
\hline & $P$ value & 0.312 & 0.425 & 0.722 & 0.177 \\
\hline & \multicolumn{5}{|l|}{ Education } \\
\hline & Illiterate & 69.9 & 76.0 & 78.8 & 93.6 \\
\hline & 8 or $<$ years of study & 71.6 & 78.7 & 86.6 & 96.7 \\
\hline & 9 years or more of study & 79.5 & 76.2 & 89.1 & 96.2 \\
\hline & P value & 0.325 & 0.663 & 0.335 & 0.834 \\
\hline & \multicolumn{5}{|l|}{ Work link } \\
\hline & Employed & 77.9 & 85.3 & 88.7 & 95.9 \\
\hline & Unemployed & 72.2 & 72.2 & 85.0 & 96.3 \\
\hline & $P$ value & 0.246 & 0.002 & 0.167 & 0.839 \\
\hline & \multicolumn{5}{|l|}{ Family income } \\
\hline & Less than $1 \mathrm{MS}$ & 72.2 & 60.5 & 89.5 & 92.1 \\
\hline & 1 to $2 \mathrm{MS}$ & 74.1 & 80.2 & 87.1 & 96.9 \\
\hline & 3 to $4 \mathrm{MS}$ & 81.3 & 82.7 & 86.3 & 97.4 \\
\hline & More than 4 MS & 76.8 & 94.4 & 85.0 & 96.6 \\
\hline & P value & 0.572 & 0.003 & 0.931 & 0.123 \\
\hline
\end{tabular}

be expressed by the care and help in performing daily activities, monitoring the consultations stimulus for maintenance treatment, and social support from family, friends and partners associated with a better QoL $^{24}$.

The concern with health domain investigates the concern of respondents in living with the virus and its consequences, and the self-assessment in relation to health, knowledge of laboratory parameters and the concern with a prognosis of death, situations that possibly prevent the well-being ${ }^{12}$. From this perspective, in the present study, the year of HIV diagnosis was associated with this domain for the reason that people with recent discovery of the infection do not accept the fact of the disease, which leads to discouragement with life and with health care, which implies low scores. In the multiple regression, the fact of not using illicit drugs had a positive association in this domain, which demonstrates the individual's care with their health and well-being.

Despite the impact of HIV / AIDS in the psychological health and social relationships of infected individuals, as well as life satisfaction, the use of ART led to a positive effect on the health, providing the deconstruction of the idea of death arising from the diagnostic of the carrier of HIV / AIDS and the construction of better prospects 
Table 4. Bivariate analysis of standardized scores of the HAT-QoL domains according to variables related to HIV and the habits of people living with HIV / AIDS assisted in the HIV / AIDS Reference Center, Vitoria, Brazil. 2012.

\begin{tabular}{|c|c|c|c|c|c|}
\hline Variables & $\begin{array}{l}\text { General } \\
\text { Activity }\end{array}$ & $\begin{array}{c}\text { Sexual } \\
\text { Activity }\end{array}$ & $\begin{array}{l}\text { Secrecy } \\
\text { Concern }\end{array}$ & $\begin{array}{c}\text { Health } \\
\text { Concern }\end{array}$ & $\begin{array}{l}\text { Financial } \\
\text { Concern }\end{array}$ \\
\hline \multicolumn{6}{|l|}{$\mathrm{CV}$} \\
\hline Undetectable & 77.4 & 53.9 & 46.1 & 65.2 & 39.3 \\
\hline$<10000$ & 73.9 & 56.9 & 42.8 & 62.6 & 44.1 \\
\hline$>10000$ & 74.2 & 59.0 & 38.3 & 60.6 & 38.3 \\
\hline $\mathrm{P}$ value & 0.689 & 0.757 & 0.290 & 0.399 & 0.796 \\
\hline \multicolumn{6}{|l|}{ CD4 } \\
\hline$<200$ & 57.4 & 59.2 & 47.2 & 72.2 & 29.8 \\
\hline From 200 to 350 & 72.9 & 60.4 & 43.3 & 54.1 & 39.8 \\
\hline$>350$ & 76.0 & 55.6 & 43.4 & 63.7 & 39.5 \\
\hline $\mathrm{P}$ value & 0.039 & 0.722 & 0.915 & 0.006 & 0.680 \\
\hline \multicolumn{6}{|l|}{ Year of HIV discovery } \\
\hline Less than 1 year & 72.7 & 52.0 & 31.2 & 41.2 & 39.1 \\
\hline From 1 to 5 years & 80.3 & 63.7 & 39.5 & 65.5 & 42.6 \\
\hline More than 5 years & 78.0 & 58.1 & 42.0 & 66.0 & 40.2 \\
\hline $\mathrm{P}$ value & 0.155 & 0.089 & 0.146 & 0.003 & 0.774 \\
\hline \multicolumn{6}{|l|}{ Contamination mode } \\
\hline Heterosexual relationship & 71.4 & 49.3 & 41.7 & 59.6 & 36.0 \\
\hline Homosexual relationship & 84.9 & 68.5 & 46.6 & 67.0 & 50.6 \\
\hline Drug use & 100.0 & 100.0 & 80.0 & 45.0 & 0 \\
\hline Blood transfusion & 69.5 & 0 & 57.5 & 70.0 & 44.0 \\
\hline Mother to child & 100.0 & 50.0 & 70.0 & 77.5 & 84.5 \\
\hline$P$ value & 0.043 & 0.026 & 0.370 & 0.146 & 0.065 \\
\hline \multicolumn{6}{|l|}{ Use of HAART } \\
\hline Yes & 76.3 & 54.7 & 45.4 & 63.3 & 39.7 \\
\hline No & 74.0 & 57.0 & 35.8 & 61.2 & 38.1 \\
\hline $\mathrm{P}$ value & 0.600 & 0.742 & 0.053 & 0.547 & 0.797 \\
\hline \multicolumn{6}{|l|}{ Abandoned use of HAART } \\
\hline Yes & 64.0 & 49.4 & 53.7 & 57.1 & 22.0 \\
\hline No & 80.6 & 55.9 & 43.0 & 65.5 & 46.0 \\
\hline $\mathrm{P}$ value & 0.000 & 0.406 & 0.048 & 0.029 & 0.000 \\
\hline \multicolumn{6}{|l|}{ Smokes } \\
\hline Yes & 75.1 & 63.5 & 39.6 & 62.7 & 25.9 \\
\hline No & 76.0 & 52.8 & 44.3 & 62.9 & 43.3 \\
\hline$P$ value & 0.978 & 0.025 & 0.721 & 0.519 & 0.602 \\
\hline \multicolumn{6}{|l|}{ Consumes alcoholic beverages } \\
\hline Yes & 77.7 & 65.3 & 38.6 & 60.4 & 33.2 \\
\hline No & 74.9 & 50.3 & 45.5 & 64.0 & 42.3 \\
\hline $\mathrm{P}$ value & 0.474 & 0.015 & 0.117 & 0.242 & 0.094 \\
\hline \multicolumn{6}{|l|}{ Use of illicit drugs } \\
\hline Yes & 71.8 & 50.8 & 55.0 & 43.7 & 26.6 \\
\hline No & 76.0 & 55.4 & 42.6 & 63.7 & 40.0 \\
\hline $\mathrm{P}$ value & 0.638 & 0.745 & 0.215 & 0.004 & 0.277 \\
\hline
\end{tabular}

for life $\mathrm{f}^{15}$. With the advent of ART, living with HIV / AIDS allowed for rethinking and reframing HIV infection, deconstructing the idea of death to a more human perspective, in which the individual lives better every day with HIV, allowing the reconstruction of professional projects and emotional life, with the insertion in the labor market and the establishment of affective-sexual links ${ }^{7}$.

The results showed sociodemographic and clinical characteristics of these individuals sim- 


\begin{tabular}{|c|c|c|c|c|}
\hline Variables & $\begin{array}{c}\text { HIV } \\
\text { Awareness }\end{array}$ & $\begin{array}{c}\text { Life } \\
\text { satisfaction }\end{array}$ & $\begin{array}{c}\text { Issues related to } \\
\text { medication }\end{array}$ & $\begin{array}{c}\text { Confidence } \\
\text { in doctor }\end{array}$ \\
\hline \multicolumn{5}{|l|}{$\mathrm{CV}$} \\
\hline Undetectable & 78.9 & 81.6 & 88.3 & 97.7 \\
\hline$<10000$ & 68.8 & 82.1 & 90.7 & 96.3 \\
\hline$>10000$ & 70.3 & 70.0 & 79.8 & 91.8 \\
\hline$P$ value & 0.196 & 0.062 & 0.016 & 0.059 \\
\hline \multicolumn{5}{|l|}{ CD4 } \\
\hline$<200$ & 79.6 & 60.5 & 82.6 & 98.1 \\
\hline From 200 to 350 & 63.4 & 73.0 & 80.7 & 91.0 \\
\hline$>350$ & 75.4 & 78.5 & 86.4 & 96.0 \\
\hline$P$ value & 0.096 & 0.058 & 0.145 & 0.112 \\
\hline \multicolumn{5}{|l|}{ Year of HIV discovery } \\
\hline Less than 1 year & 61.3 & 70.3 & 78.7 & 86.5 \\
\hline From 1 to 5 years & 70.0 & 79.6 & 86.5 & 94.5 \\
\hline More than 5 years & 77.6 & 84.6 & 89.2 & 96.9 \\
\hline $\mathrm{P}$ value & 0.294 & 0.126 & 0.447 & 0.098 \\
\hline \multicolumn{5}{|l|}{ Contamination mode } \\
\hline Heterosexual relationship & 69.8 & 74.9 & 83.3 & 95.1 \\
\hline Homosexual relationship & 87.7 & 88.1 & 90.2 & 96.7 \\
\hline Drug use & 100.0 & 81.0 & 81.0 & 100.0 \\
\hline Blood transfusion & 100.0 & 100.0 & 94.0 & 100.0 \\
\hline Mother to child & 100.0 & 94.0 & 100.0 & 100.0 \\
\hline $\mathrm{P}$ value & 0.046 & 0.167 & 0.096 & 0.891 \\
\hline \multicolumn{5}{|l|}{ Use of HAART } \\
\hline Yes & 77.5 & 80.8 & 88.4 & 97.8 \\
\hline No & 66.2 & 70.5 & 81.3 & 90.6 \\
\hline$P$ value & 0.051 & 0.040 & 0.028 & 0.003 \\
\hline \multicolumn{5}{|l|}{ Abandoned use of HAART } \\
\hline Yes & 61.4 & 65.6 & 83.0 & 97.9 \\
\hline No & 82.3 & 85.8 & 90.1 & 97.7 \\
\hline$P$ value & 0.000 & 0.000 & 0.075 & 0.930 \\
\hline \multicolumn{5}{|l|}{ Smokes } \\
\hline Yes & 79.1 & 73.1 & 83.7 & 98.7 \\
\hline No & 73.7 & 80.1 & 87.7 & 95.4 \\
\hline $\mathrm{P}$ value & 0.816 & 0.930 & 0.064 & 0.103 \\
\hline \multicolumn{5}{|l|}{ Consumes alcoholic beverages } \\
\hline Yes & 75.4 & 78.5 & 85.1 & 95.8 \\
\hline No & 74.7 & 78.5 & 87.6 & 96.3 \\
\hline$P$ value & 0.897 & 0.993 & 0.379 & 0.810 \\
\hline \multicolumn{5}{|l|}{ Use of illicit drugs } \\
\hline Yes & 61.5 & 55.3 & 68.7 & 89.6 \\
\hline No & 75.6 & 79.6 & 87.6 & 96.4 \\
\hline $\mathrm{P}$ value & 0.229 & 0.016 & 0.003 & 0.162 \\
\hline
\end{tabular}

ilar to other surveys conducted with Brazilian people living with HIV / AIDS ${ }^{10,12,20}$. There are some limitations in this study, such as the voluntary participation of respondents, which may have had moreindividuals concerned with their health and higher education. The study is of cross-sectional nature, which precludes causal inferences. Due to the nature of the study of anonymity, itis not possible to collect any information about those who did not answer the questionnaire completely. The instrument of quality of life, though it may be validated in Portuguese, 
Table 5. Multiple linear regression for the quality of life variable of people living with HIV / AIDS assisted in the HIV / AIDS Reference Center, Vitoria, Brazil. 2012.

\begin{tabular}{llrl}
\hline \multicolumn{1}{c}{ HAT-Qol quality of life domains } & \multicolumn{1}{c}{ Explanatory variables } & B & P value \\
\hline Financial Concern (0.462) & Presents 9 years or more of studies & 10.430 & 0.002 \\
& Non smoker & 19.784 & 0.002 \\
Concern with secrecy ( $\mathrm{r}=0.311)$ & No work link & -15.601 & 0.004 \\
& More advanced age & 7.534 & 0.007 \\
Sexual Activity ( $\mathrm{r}=0.318)$ & Is brown or black & -5.684 & 0.045 \\
& No work link & -19.943 & 0.001 \\
Health Concern (0.437) & Consumes alcoholic beverages & -12.758 & 0.041 \\
& Is of the masculine gender & 10.289 & 0.001 \\
& Does not use illicit drugs & 20.722 & 0.006 \\
& Is 18 to 34 years of age & 3.890 & 0.046 \\
\hline
\end{tabular}

$\mathrm{B}=$ coefficient of the regression model, $\mathrm{r}=$ coefficient of determination.

and the educational level of the respondents may have had answers in which participants answered even without understanding the question.

Despite these limitations, the study shows that there are many factors that influence the quality of life of people living with HIV / AIDS, and socioeconomic and inadequate health conditions negatively influence the quality of life of these individuals. From these results, the need to implement public policies for social inclusion that promote better living conditions is evident, greater access to health services and the formal labor market, to foster the scope of citizenship and a better QoL for people living with HIV / AIDS.

Understanding the quality of life of these people is critical, considering the chronic course of infection, the possibility of treatment and longer survival and living with a stigmatizing, transmitted, incurable disease so far, with numerous biopsychosocial consequences that impact the quality of life.

\section{Collaborations}

GB Soares, CAS Garbin, TAS Rovida and AJI Garbin also participated in all stages of the preparation of the article. 


\section{References}

1. Mahy M, Warner-Smith M, Stanecki KA, Ghys PD. Measuring the impact of the global response to the AIDS epidemic: challenges and future directions. J Acquir Immune Defic Syndr 2009; 52(Supl. 2):152-159.

2. Boletim Epidemiológico Aids e DST. Programa Nacional de DST e Aids. Brasília: Ministério da Saúde (MS) 2013; $1(1)$.

3. World Health Organization (WHO), UNAIDS. AIDS Epidemic Update: Joint United Nations Programme on HIV/AIDS and World Health Organization. Geneva: WHO; 2013.

4. Lohse N, Hansen AB, Pedersen G, Kronborg G, Gerstoft J, Sørensen HT, Vaeth M, Obel N. Survival of persons with and without HIV infection in Denmark, 1995-2005. Ann Intern Med 2007; 146(2):87-95.

5. Brasil. Ministério da Saúde (MS). Terapia anti-retroviral e saúde pública: um balanço da experiência brasileira. Brasília: MS; 1999.

6. Hacker MA, Kaida A, Hogg RS, Bastos FI. The first ten years: achievements and challenges of the Brazilian program of universal access to HIV/AIDS comprehensive management and care, 1996-2006. Cad Saude Publica 2007; 23(Supl. 3):345-349

7. Schaurich D, Coelho DF, Motta MGC. A Cronicidade no Processo Saúde-Doença: repensando a epidemia da Aids após os anti-retrovirais. Rev Enferm UERJ 2006; 14(3):455-462.

8. Olejack L, Seidl EMF. Monitoramento e avaliação da adesão ao tratamento antirretroviral para HIV/ aids: desafios e possibilidades. Cien Saude Colet 2010; 15(Supl. 1):1201-1208.

9. The Antiretroviral Therapy Cohort Collaboration. Life expectancy of individuals on combination antiretroviral therapy in high-income countries: a collaborative analysis of 14 cohort studies. Lancet 2008; 372(9635):293-299.

10. Reis RK, Santos CB, Gir E. Quality of life among Brazilian women living with HIV/Aids. Aids Care 2012; 24(5):626-634.

11. Holmes WC, Shea JA. Performance of a new, HIV/ AIDS-targeted quality of life (HAT-QoL) instrument in asymptomatic seropositive individuals. Quality of Life Research 1997; 6(6):561-571.

12. Galvão MTG, Cerqueira ATAR, Marcondes-Machadon J. Evaluation of quality of life among women with HIV/AIDS using HAT-Qol. Cad Saude Publica 2004; 20(2):430-437.

13. Brito AM, Castilho EA,Szwarcwald CL .AIDS and HIV infection in Brazil: a multifaceted epidemic. Rev Soc Bras Med Trop 2001; 34(2):207-217.
14. Mulligan R, Seirawan H, Alves ME, Navazesh M, Phelan JA, Greenspan D. Oral health-related quality of life among HIV-infected and at-risk women. Community Dent Oral Epidemiol 2008; 36(6):549-557.

15. Reis RK, Santos CB, Spadoti Dantas RA, Gir E. Quality of life, sociodemographic factores and sexuality of people living with HIV / AIDS. Texto \& contexto enferm 2011; 20(3):365-375.

16. Souza PB, Oliveira CMC, Reis, Costa HS, Silva CAL, Silva VS. Fatores associados à infecção pelo HIV/AIDS entre adolescentes e adultos jovens matriculados em Centro de Testagem e Aconselhamento no Estado da Bahia, Brasil. Cien Saude Colet 2014; 19(3):747-758.

17. Jia H, Uphold CR, Zheng Y, Wu S, Chen GJ, Findley K.A further investigation of health-related quality of life over time among men with HIV infection in the HAART era. Qual Life Res 2007; 16(6):961-968.

18. Santos EMC, Franca Júnior I, Lopes F. Quality of life of people living with HIV/AIDS in São Paulo. Rev Saude Publica 2007; 41(2):64-71.

19. Reis RK, Santos CB, Gir E. Quality of life among Brazilian women living with HIV/Aids. Aids Care 2012; 24(5):626-634.

20. Garbin CAS, Garbin AJI, Moimaz SAS, Carmo MP. Bioética e HIV/AIDS: discriminação no atendimento aos portadores. Rev Bioética 2009, 17(3):511-522.

21. Lelis RT, Garbin CAS, Garbin AJI, Soares GB. Vivendo com HIV/AIDS: estudo da ocorrência de discriminação nos serviços de saúde. Rev Bras Pesq Saúde 2012; 14(4):22-28.

22. Grimberg M. Género y VIH/SIDA: un análisis de los diferenciales de género enlaexperiencia de vivircon VIH. Cuadernos Medico Sociales 2000; (78):41-54.

23. Paiva V, Latorre MR, Gravato N, Lacerda R. Sexualidade de mulheres vivendo com HIV/Aids em São Paulo. Cad Saude Publica 2002; 18(6):1609-1620.

24. Viswanathan H, Anderson R, Thomas J. Nature and correlates of SF-12 physical and mental quality of life components among low-income HIV adults using an HIV service center. Qual Life Res 2005; 14(4):935-944.

Article submitted 06/07/2014

Approved 08/10/2014

Final version submitted 08/24/2014 